STUDIA PRAWNO-EKONOMICZNE, T. CVIII, 2018

PL ISSN 0081-6841; e-ISSN 2450-8179 s. 319-332

https://doi.org/10.26485/SPE/2018/108/18

\title{
Krzysztof SZCZYGIELSKI*
}

\section{PROBLEM AUTONOMII PROFESJONALNEJ JAKO PRZEDMIOT ANALIZY EKONOMICZNEJ1}

\begin{abstract}
(Streszczenie)
Termin profesje albo grupy profesjonalne odnosi się do pewnych specyficznych grup zawodowych. Charakterystyczną, ale nie jedyną cechą profesji jest świadczenie przez nie usług o wysokim stopniu asymetrii informacyjnej: przeciętny klient nie potrafi ocenić jakości usługi. Klasycznymi przykładami grup profesjonalnych są lekarze i prawnicy, ale wiele innych grup zawodowych wykazuje przynajmniej niektóre cechy profesji. W opracowaniu podjęto próbę podsumowania i oceny dorobku teorii ekonomii w zakresie analizy działania grup profesjonalnych, w szczególności uzasadnienia i skutków ich autonomii regulacyjnej. Literatura teoretyczna została omówiona w podziale na trzy obszary: grupy profesjonalne a bariery wejścia do gałęzi, organizacja profesjonalna jako gwarant jakości i działanie organizacji profesjonalnych a możliwe interwencje rządu. Przedstawione w artykule badania teoretyczne wskazują, że jakkolwiek istnienie organizacji profesjonalnych ma w pewnym sensie uzasadnienie ekonomiczne, to organizacje takie mają skłonność do tworzenia barier wejścia. Państwo nie powinno całkowicie wycofywać się $\mathrm{z}$ regulowania rynków profesjonalnych. W artykule zasugerowano też możliwe kierunki dalszych badań nad profesjami.
\end{abstract}

Słowa kluczowe: grupy profesjonalne; autonomia zawodowa; samoregulacja; asymetria informacyjna

Klasyfikacja JEL: K20, K23, L51, D82

* Dr, Uniwersytet Warszawski, Wydział Nauk Ekonomicznych, Katedra Makroekonomii i Teorii Handlu Zagranicznego; e-mail: kszczygielski@coin.wne.uw.edu.pl

1 Artykuł powstał w ramach projektu „Autonomia czy regulacja z zewnątrz? Ekonomiczna analiza problemu samorządów zawodowych", finansowanego przez Narodowe Centrum Nauki (UMO-2013/09/D/HS4/01046). 


\section{Wprowadzenie}

Przedmiotem opracowania jest ekonomiczna teoria autonomii grup profesjonalnych, czyli tych grup zawodowych, które w Polsce często nazywane są, zgodnie z nomenklaturą nauk politycznych, „korporacjami”: mówi się np. o „korporacji lekarskiej” czy „korporacji adwokackiej”. W literaturze anglojęzycznej grupy te noszą nazwę professions i właśnie najbliższe możliwe spolszczenia tego terminu - profesje, profesjonaliści lub grupy profesjonalne - jest stosowane w artykule. Jakkolwiek lekarze czy prawnicy są najlepszymi przykładami grup profesjonalnych, pojęcie to jest szersze i obejmuje także niektóre inne zawody. Można wskazać następujące kluczowe cechy profesji:

a) Produktem profesjonalistów są raczej usługi niż dobra;

b) Usługi świadczone przez profesjonalistów charakteryzują się asymetrią informacyjną: klient często nie jest w stanie ocenić jakości oferowanego mu produktu przed zakupem (experience good), a najczęściej także po zakupie (credence good);

c) Istnieje sformalizowany lub domyślny kodeks etyczny profesji;

d) Profesje zwykle cieszą się dużym społecznym uznaniem;

e) Warunkiem wykonywania profesji jest zdobycie odpowiedniego wykształcenia, często nie tylko w toku studiów, ale również w ramach zinstytucjonalizowanego systemu praktyk;

f) Istnieje system dopuszczenia do zawodu działający (faktycznie lub tylko pozornie) na zasadzie sprawdzania kompetencji kandydatów;

g) Grupa profesjonalna ma charakter zinstytucjonalizowany i pełni istotne funkcje, takie jak wpływanie, w sposób sformalizowany lub nieformalny, na wspomniane wcześniej systemy kształcenia i dopuszczenia do zawodu, ustalanie standardów świadczonych usług, a także nakładanie na członków profesji innych ograniczeń ${ }^{2}$ i egzekwowanie ich (np. pod karą wydalenia z zawodu);

h) Organizacja profesjonalna reprezentuje profesjonalistów wobec innych istotnych podmiotów, w szczególności rządu.

Jak widać, to, czy daną grupę zawodową nazwiemy profesją, zależy zarówno od właściwości świadczonych przez nią usług, jak i od instytucji społecz-

2 Ograniczenia mogą dotyczyć reklamy, formy prawnej, w jakiej wykonuje się działalność gospodarczą, czy zakazu delegowania obowiązków na osoby spoza profesji (A. Ogus, Self-regulation, w: B. Bouckaert, G. de Geest (eds.), Encyclopedia of Law and Economics, t. 5, Edward Elgar, Cheltenham 2000, s. 592). 
nych i prawnych. Dlatego niektóre zawody w jednym kraju mogą być uznane za profesje, a w innym już niekoniecznie. Status profesjonalny konkretnego zawodu może też zmieniać się w czasie. Jak pisze Larson, „zjawisko profesjonalizmu nie ma jasnych granic"’.

Istnieje spora literatura socjologiczna na temat profesji, zapoczątkowana przeszło 80 lat temu książką Carra-Saundersa i Wilsona ${ }^{4}$ i bazująca na analizie przypadków konkretnych grup profesjonalnych ${ }^{5}$. Ekonomia zajęła się tematem grup profesjonalnych nieco później: jedną z pierwszych prac była książka Friedmana i Kuznetsa ${ }^{6}$, którzy analizowali dochody wybranych profesji. Modele teoretyczne pojawiły się na przełomie lat 1970 i 1980 i choć z pewnością nie jest to temat wiodaccy w mikroekonomii czy organizacji rynku, to jest on podejmowany w literaturze do dziś. Równolegle rozwijają się badania poświęcone samoregulacji biznesu (self-regulation), czyli dobrowolnemu zobowiązywaniu się firm do pewnego rodzaju działań (np. ograniczeniu emisji substancji toksycznych). Jakkolwiek ten nurt literatury jest inspirowany innymi rynkami niż sektory usług profesjonalnych, to jego dorobek ma zastosowanie również do nich? ${ }^{7}$.

3 M.S. Larson, The Rise of Professionalism: Monopolies of Competence and Sheltered Markets, wyd. 2, Transaction Publishers, New Brunswick 2013, s. xi.

Ciekawym przypadkiem jest zawód psychologa w Polsce. Ma on niewątpliwie potencjał, aby stać się profesją w znacznym stopniu podobną do lekarskiej, ale ze względu na brak uregulowań prawnych (wciąż nie ma rozporządzeń wykonawczych do Ustawy o zawodzie psychologa uchwalonej w 2001 r.!), nie spełnia warunków (e)-(h).

4 A.M. Carr-Saunders, P.A. Wilson, The Professions, Oxford University Press, Oxford 1933, cyt. za: A. Abbott, The System of Professions: An Essay on the Division of Expert Labor, University of Chicago Press, Chicago 2014, s. 10.

5 Wśród najważniejszych publikacji socjologicznych należy wymienić książki: Freidsona, Abbota, Krausego oraz Larson (E. Freidson, The Hospital in Modern Society, Free Press of Glencoe, New York 1963; idem, Profession of Medicine, Dodd \& Mead, New York 1970; idem, Professionalism, the third logic: on the practice of knowledge, University of Chicago Press, Chicago 2001; A. Abbott, The System of Professions: An Essay on the Division of Expert Labor, University of Chicago Press, Chicago 2014; E.A Krause, Death of the Guilds: Professions, States, and the Advance of Capitalism, 1930 to the Present, Yale University Press, New Haven 2016; M.S. Larson, op. cit.).

6 M. Friedman, S. Kuznets, Income from Independent Professional Practice, National Bureau of Economic Research, Cambridge, MA 1954. Badano sytuację lekarzy, prawników, biegłych rewidentów, dentystów i inżynierów.

7 Z prawnego punktu widzenia sprawa jest bardziej skomplikowana, można bowiem wyróżnić wiele rodzajów samoregulacji. Ogus proponuje dwa wymiary analizy: stopień autonomii podmiotów podejmujących zobowiązanie (czy mają pełną swobodę, czy np. ich propozycje 
Niniejszy artykuł jest poświęcony jednemu z kluczowych aspektów działania grup profesjonalnych, a mianowicie ich autonomii w zakresie dopuszczania na rynek nowych podmiotów oraz ustalania i egzekwowania standardów jakości usług. Celem opracowania jest podsumowanie i ocena dorobku teorii ekonomii oraz sformułowanie możliwych kierunków dalszych badań. Prace teoretyczne zostaną omówione w podziale na trzy obszary tematyczne. Najpierw, w podrozdziale 2, przedstawiony zostanie problem barier wejścia do profesji i renty monopolistycznej przypadającej tym, którzy mogą oferować usługi profesjonalne. W podrozdziale 3 omówione zostaną działania profesji w celu dyscyplinowania producentów już dopuszczonych do wykonywania zawodu. Kolejny istotny obszar - możliwe kierunki interwencji rządu - zostanie przedyskutowany w podrozdziale 4 . Wnioski z omówionych badań oraz możliwe kierunki dalszych studiów zostaną przedstawione w podrozdziale 5 .

\section{Organizacja profesjonalna a bariery wejścia}

Prawo profesji do oceniania kompetencji kandydatów i do dopuszczania ich bądź nie do wykonywania zawodu implikuje oczywiście możliwość stworzenia swoistego oligopolu. Następujące w ten sposób ograniczenie konkurencji na rynku powinno mieć jednak legitymację w postaci troski profesji o jakość usług. Taka sytuacja jest właśnie przedmiotem artykułu Shakeda i Suttona ${ }^{8}$, którzy zakładają, że jest dane pewne spektrum potencjalnych dostawców, zróżnicowanych względem jakości oferowanych usług, z których, poprzez określenie minimalnej jakości, wytworzyć się może grupa czy organizacja profesjonalna (professionals). Ci którzy nie wejdą w skład organizacji, czyli zwykli dostawcy (labourers), uzyskają pewien dany egzogenicznie poziom dochodu. Autorzy wykazują, że jeśli kryterium decydowania o minimalnej jakości będzie maksymalizacja przeciętnego dochodu profesjonalisty, to jakość ta zostanie ustalona na poziomie wyższym niż społecznie optymalny. W modelu zakłada się, że konsumenci nie znają, co prawda, jakości usługi konkretnego producenta, ale mają pełną wiedzę na temat spektrum jakości organizacji profesjonalnej.

musi zatwierdzić jakiś organ państwowy) oraz to, czy przyjęte normy są wiążące, czy tylko zalecane (A. Ogus, Self-regulation w: B. Bouckaert, G. de Geest (eds.), op. cit., s. 587-602).

8 A. Shaked, J. Sutton, The Self-Regulating Profession, Review of Economic Studies 1981/48 (2), s. 217-234. 
Podejście zaproponowane $\mathrm{w}$ modelu Lelanda ${ }^{9}$ jest trochę podobne. Tu również analizowany jest rynek z asymetrią informacyjną. Leland zakłada, że na rynku działają producenci oferujący różne poziomy jakości i przyjmuje za Akerlofem $^{10}$, że konsumenci będą znać przeciętną jakość usługi. Tak jak u Akerlofa, przeciętny poziom jakości w równowadze bez regulacji będzie niższy od społecznie optymalnego. Ustanowienie minimalnego dopuszczalnego poziomu jakości może poprawić dobrobyt społeczny w porównaniu z wolnym rynkiem, ale jeżeli o tym minimum będą decydować sami producenci, to będzie ono zbyt wysokie w stosunku do poziomu społecznie optymalnego.

Tymczasem, jeżeli założyć, że konsumenci nie znają nawet jakości organizacji, wnioski mogą być trochę inne. W innym modelu Shakeda i Suttona ${ }^{11}$ konsumenci, którzy żyją skończoną liczbę okresów, aktualizują swoją ocenę jakości grupy profesjonalnej na podstawie doświadczeń. Okazuje się, że istnieje pewna krytyczna liczba producentów, poniżej której organizacja nie powinna się skurczyć - jeżeli to zrobi, zbyt niewielu konsumentów dowie się o oferowanej jakości, popyt na usługi profesjonalne spadnie i przeciętny dochód w profesji zmniejszy się.

Willner ${ }^{12}$ bada problem wielkości organizacji, stosując całkowicie inny sposób modelowego ujęcia usług profesjonalnych. Co prawda, w jego pracy występuje pionowe zróżnicowanie dobra, ale już nie asymetria informacyjna: zarówno producent, jak i konsument znają prawdziwą jakość produktu. Poziom tej jakości oraz liczba producentów jest ustalana przez organizację profesjonalną. Można więc powiedzieć, że nie ma, co prawda, asymetrii informacyjnej, ale jest jakaś przewaga profesjonalistów, którą interpretuje się jako przewagę opartą na kompetencjach. W zależności od celu organizacji profesjonalnej, różne cechy funkcji popytu mają wpływ na optymalną jakość i liczbę producentów.

9 H.E. Leland, Quacks, Lemons, and Licensing: A Theory of Minimum Quality Standards, Journal of Political Economy 1979/87 (6), s. 1328-1346.

10 G.A. Akerlof, The market for "lemons": Quality uncertainty and the market mechanism, Quarterly Journal of Economics 1970/84/3, s. 488-500.

11 A. Shaked, J. Sutton, Imperfect information, perceived quality, and the formation of professional groups, Journal of Economic Theory 1982/27 (1), s. 170-181.

12 J. Willner, Professional associations and their members: A study of the market for professional services when ability and size are independent, International Journal of Industrial Organization 1985/3 (2), s. 179-195. 


\section{Organizacja profesjonalna jako gwarant jakości}

Kwestia reputacji organizacji profesjonalnej ma fundamentalne znaczenie w drugim ze wspomnianych obszarów tematycznych: egzekwowaniu standardów profesjonalnych. Temat ten jest zresztą istotny także na innych rynkach, np. w sektorze finansowym, który jest inspiracją dla pracy Gehriga i Josta ${ }^{13}$. Rozważają oni model dwuookresowy, w którym konsumenci - którzy z okresu na okres mogą zmienić dostawców - nie znają jakości dostawcy w pierwszym okresie, ale w drugim, po konsumpcji, już tak. Jakość dobra jest zawsze ustalona na oba okresy. Nietrudno pokazać, że jakość w równowadze jest niższa niż by była w warunkach pełnej informacji. Gehrig i Jost rozważają samoregulację w postaci ustalenia standardu jakości, którego niedotrzymanie w pierwszym okresie będzie skutkowało odebraniem „certyfikatu jakości” w drugim okresie. Autorzy pokazują, że samoregulacja jest opłacalna tylko wtedy, gdy odpowiednio dużo klientów zmienia dostawców w drugim okresie. W podobnym duchu utrzymana jest praca Chaserant i Harnay ${ }^{14}$. Choć budowanie reputacji jest modelowane w inny sposób (model nakładających się pokoleń producentów), tutaj także dodatkowy mechanizm kontroli jakości ułatwia uzyskanie stanu ustalonego z wysoką jakością i wyższą ceną dobra.

We wszystkich omówionych dotychczas modelach organizacja profesjonalna jest wprowadzona jako pewna zmienna decyzyjna producentów. W modelu Núñeza organizacja jest osobnym podmiotem realizującym własną strategię $^{15}$. Núñez proponuje model typu principal-agent (mocodawca-pełnomocnik), w którym organizacja jest mocodawcą, zaś (reprezentatywny) producent jest pełnomocnikiem. Konsument płaci za dobro cenę, która zależy tylko od reputacji grupy. Użyteczność organizacji jest rosnąca względem tej ceny oraz względem łapówki, jaką płaci jej producent za zatajenie wykrycia niedopatrzenia (cover-up). Organizacja decyduje o tym, jak dokładna będzie kontrola producenta, o tym, czy poinformować konsumentów o wykrytym niedopatrzeniu oraz ewentualnie o tym, czy przyjąć łapówkę. Producent decyduje o poziomie niedopatrzenia i ewentualnie o tym, czy zapłacić łapówkę. W pracy wykazano, że po-

T. Gehrig, P.-J. Jost, Quacks, lemons, and self-regulation: A welfare analysis, Journal of Regulatory Economics 1995/7.3, s. 309-325.

14 C. Chaserant, S. Harnay, Self-regulation of the legal profession and quality in the market for legal services: an economic analysis of lawyers' reputation, European Journal of Law and Economics 2015/39 (2), s. 431-449.

15 J. Núñez, Can self-regulation work?: a story of corruption, impunity and cover-up, Journal of Regulatory Economics 2007/31 (2), s. 209-233. 
ziom dokładności kontroli będzie wyższy od minimalnego, tylko jeżeli większa dokładność kontroli poprawia szanse na wykrycie niedopatrzenia. Jednak nawet wtedy może dojść do skorumpowania organizacji, jeżeli zysk na reputacji wynikający z ujawnienia niedopatrzenia będzie niewielki. Prostsza wersja modelu ${ }^{16}$ została poddana testowi w postaci eksperymentu ekonomicznego przez Limę i Núñeza ${ }^{17}$. Dla wyniku eksperymentu kluczowe znaczenie miało to, czy gracze rozumieli związek między dokładnością kontroli a wykryciem niedopatrzenia: jeżeli tak, to zachowywali się zgodnie z przewidywaniami modelu, w przeciwnym wypadku wyniki były niejasne.

De Marzo, Fishman i Hagerty ${ }^{18}$ także myślą o organizacji profesjonalnej jako o osobnym podmiocie, ale jednak takim, którego celem jest maksymalizacja użyteczności profesjonalistów. Konsument i producent zawierają umowę co do tego, jaką wypłatę otrzyma konsument, przy jakiej realizacji zmiennej losowej (prywatna informacja producenta). Producent musi liczyć się z ryzykiem kontroli (na koszt konsumenta) i kary, jeśli poda fałszywą informację. Organizacja profesjonalna decyduje o prawdopodobieństwie kontroli i określa jej koszt. Autorzy pokazują, że w tym przypadku producent wydrenuje konsumenta z jego nadwyżki. Sytuacja może się zmienić, jeśli pojawi się ryzyko dodatkowej kontroli rządowej, o czym więcej poniżej.

Jak wspomniano we Wstępie, jedną z charakterystycznych cech profesji jest wypracowanie etosu grupy. Naturalne wydaje się więc uwzględnienie w modelu niepieniężnych motywów działalności. Baron ${ }^{19}$ bada samoregulację rozumianą jako altruistyczne zachowanie w grupie. Rozróżnia dwa rodzaje motywów takiego zachowania: wewnętrzna potrzeba zachowywania się w sposób etyczny oraz chęć pomagania tym, którzy są blisko nas w przestrzeni społecznej. Pierwszy motyw jest istotny, bo może skłaniać do altruizmu nawet wtedy, gdy nie spodziewamy się wzajemności. Drugi motyw wyznacza granice zachowania etycznego (granice w sensie dystansu społecznego modelowanego jako dystans geograficzny). Baron analizuje różne rodzaje możliwych organizacji, które mogą powiększyć grupę, wobec której dany podmiot zachowuje się etycznie. Dwie najważniejsze z nich to „organizacja dyscyplinująca” (w oryginale

6 J. Núñez, A model of self-regulation, Economics Letters 2001/74 (1), s. 91-97.

17 J.L. Lima, J. Núñez, Does self-regulation work? Experimental evidence of the reputational incentives of Self-Regulatory Organizations, Applied Economics 2015/47 (41), s. 4423-4441.

18 P.M. DeMarzo, M.J. Fishman, K.M. Hagerty, Self-Regulation and Government Oversight, Review of Economic Studies 2005/72 (3), s. 687-706.

19 D.P. Baron, Morally Motivated Self-Regulation, American Economic Review 2010/100 (4), s. $1299-1329$. 
assurance organization ${ }^{20}$ ) i „organizacja ujawniająca” (informational organization). Pierwsza nakłada na członków karę, jeżeli nie zachowają się altruistycznie, druga tylko pobiera opłatę i wydaje certyfikaty, co pozwala „altruistom” zasygnalizować ich typ.

\section{Działanie organizacji profesjonalnych a możliwe interwencje rządu}

Wszystkie omówione tu modele wyjaśniają powstanie organizacji profesjonalnych występowaniem zawodności rynku, a ściślej asymetrii informacyjnej. W tej sytuacji rozwiązanie wolnorynkowe może nie być społecznie optymal-

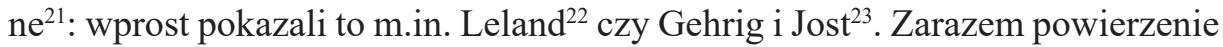
zadania uregulowania rynku organizacji profesjonalnej sprawia, że producenci zrealizują zysk nadzwyczajny poprzez np. ustalenie zbyt wysokich barier wejścia na rynek ${ }^{24}$. Czy rząd może podjąć jakieś działania, tak aby poprawić sytuację konsumentów albo wręcz zwiększyć dobrobyt społeczny?

Okazuje się, że tak, co więcej, teoria sugeruje różne możliwe rozwiązania. We wspomnianej już pracy Shaked i Sutton ${ }^{25}$ pokazują, że dla społecznego dobrobytu korzystne będzie pozwolenie na utworzenie dodatkowej grupy producentów: „paraprofesjonalistów”. Autorzy dowodzą też, że profesjonaliści mogą zapobiec powstaniu nowej grupy, jeżeli ustalą odpowiednio nisko próg wstępu do własnej profesji. Sugeruje to, że sama możliwość oferowania przez producentów usług paraprofesjonalnych jest w interesie konsumentów. Ogus ${ }^{26}$ określa to rozwiązanie mianem „konkurencyjnej samoregulacji” (competitive self-regulation).

20 Tłumaczenie jest celowo niedokładne; chodzi o to, żeby oddać sposób działania organizacji.

21 Jak pokazali Dulleck i Kerschbamer, rynek zapewni rozwiązanie optymalne, jeżeli spełnione są pewne warunki. Są one jednak dość silne - de facto eliminują niektóre rodzaje nieuczciwych zachowań; ponadto konsumenci muszą być homogeniczni (U. Dulleck, R. Kerschbamer, On Doctors, Mechanics, and Computer Specialists: The Economics of Credence Goods, Journal of Economic Literature 2006/XLVI, s. 5-42).

22 H.E. Leland, op. cit.

23 T. Gehrig, P.J. Jost, op. cit.

24 Ogus stawia tezę, że samoregulacja ma większe szanse poprawić dobrobyt społeczny, kiedy występuje spontanicznie, natomiast kiedy jest li tylko wynikiem przywileju nadanego przez rząd, to jest większe zagrożenie, że będzie skutkować ograniczeniem konkurencji i drenowaniem nadwyżki konsumenta (A. Ogus, Self-regulation...).

25 A. Shaked, J. Sutton, The Self-Regulating Profession, Review of Economic Studies 1981/48 (2), s. 217-234.

26 A. Ogus, Rethinking Self-Regulation, Oxford Journal of Legal Studies 1995/15 (1), s. 97-108. 
W rozwinięciu wspomnianego wcześniej modelu DeMarzo, Fishmana i Hagerty ${ }^{27}$ działa trochę podobny mechanizm. Jeżeli do ich modelu wprowadzić rząd, który może kontrolować producentów w tych przypadkach, kiedy nie robi tego organizacja profesjonalna, to sytuacja konsumentów się poprawi, mimo że w równowadze groźba kontroli rządu nigdy nie zostanie zrealizowana. Organizacja zwiększy bowiem dokładność swojej kontroli, a producenci będą przekazywać konsumentowi więcej dobra. Weryfikacja eksperymentalna tego modelu, autorstwa Van Kotena i Ortmanna ${ }^{28}$, pokazała, że w około 50-60\% przypadków grali zgodnie z przewidywaniami modelu DeMarzo.

Jako model regulacji można interpretować kolejny artykuł Barona ${ }^{29}$, chociaż w zamierzeniu jest to studium rozgrywki prowadzonej między organizacją producentów (credence organization) a organizacją pozarządową (social activist), której przedmiotem jest poziom jakości dobra. Gra między organizacjami jest prowadzona według modelu Tullocka ${ }^{30}$ interpretowanego jako kampania informacyjna. Baron pokazuje, że działanie organizacji pozarządowej wpłynie na poprawę jakości dobra, choć całkowita podaż jakości będzie nadal mniejsza niż optimum społeczne. $\mathrm{W}$ istocie, gdyby zamiast o organizacji pozarządowej myśleć o rządzie, a zamiast o kampanii informacyjnej o kampanii legislacyjnej i działaniach urzędów - to model Barona mówi nam coś o sensowności i ograniczeniach polityki gospodarczej. Podobny pod wieloma względami jest model Maxwella, Lyona i Hacketta ${ }^{31}$.

Co ważne, zarówno w modelu Maxwella i in., jak i w pracy DeMarzo, Fishmana i Hagerty motywem samoregulacji jest chęć zapobieżenia działaniom konsumentów czy rządu ${ }^{32}$. Stefanadis ${ }^{33}$ dowodzi, że rząd może cofnąc się przed

27 P.M. DeMarzo, M.J. Fishman, K.M. Hagerty, op. cit.

28 S. Van Koten, A. Ortmann, Self-regulatory organizations under the shadow of governmental oversight: an experimental investigation, w: S.J. Goerg, J.R. Hamman, Experiments in Organizational Economics, Emerald Group Publishing Limited, Bingley 2016, s. 85-104.

29 D.P. Baron, Credence attributes, voluntary organizations, and social pressure, Journal of Public Economics 2011/95 (11-12), s. 1331-1338.

30 G. Tullock, Efficient rent seeking, w: J.B. Buchanan, R.D. Tollison, G. Tullock (eds.), Toward a theory of the rent-seeking society, Texas A\&M University Press, College Station 1980.

31 J.W. Maxwell, T.P. Lyon, S.C. Hackett, Self-regulation and social welfare: The political economy of corporate environmentalism, The Journal of Law and Economics 2000/43 (2), s. 583-618.

32 Zarówno Maxwell, Lyon i Hackett, jak i Ogus (Self-regulation ...) przytaczają badania empiryczne na potwierdzenie, że firmy faktycznie tak postępują.

33 C. Stefanadis, Self-Regulation, Innovation, and the Financial Industry, Journal of Regulatory Economics 2003/23 (1), s. 5-25. 
regulacją nie tylko dla uniknięcia związanych z nią kosztów, ale także po to, aby umożliwić szybsze wprowadzanie do gospodarki innowacji.

Rząd może też wpłynąć na działanie grupy profesjonalnej poprzez przejęcie funkcji dostawcy usług, tak jak się to stało $\mathrm{w}$ wielu krajach $\mathrm{z}$ usługami zdrowotnymi. Kundu i Szczygielski ${ }^{34}$ analizują ten przypadek w modelu podobnym do tego, jaki zaproponował Baron ${ }^{35}$. Organizacja profesjonalna ustala jakość dobra, ale rząd może wprowadzić na rynek dobro niższej jakości, oferowane bezpłatnie za pieniądze z podatków. Takie działanie będzie społecznie korzystne, jeżeli tylko jednostkowy koszt produkcji rośnie wystarczająco szybko względem jakości.

Jeżeli rząd kupuje od profesjonalistów dobro publiczne albo, tak jak w przypadku usług zdrowotnych, dobro prywatne, ale oferowane nieodpłatnie, to pojawia się problem asymetrii informacyjnej między rządem a profesjonalistami. Praca Szczygielskiego ${ }^{36}$ sugeruje, że rząd może wykorzystać heterogeniczność profesjonalistów, aby poprawić dobrobyt społeczny, jeżeli odpowiednio zostanie zaprojektowany mechanizm konsultacji z profesjonalistami.

Wreszcie, jak pokazał Heyes ${ }^{37} \mathrm{w}$ modelu dwuokresowym, perspektywa interwencji rządu w działanie rynku $\mathrm{z}$ asymetrią informacyjną może sprawić, że część producentów sama stworzy organizację narzucającą standard jakości. Ściślej, producentom nieefektywnym opłaca się narzucić sobie standard jakości w pierwszym okresie, aby w ten sposób zasygnalizować swój typ i zostać łagodniej potraktowanym $\mathrm{w}$ drugim okresie. Trochę podobny pomysł pojawił się wcześniej u Grabosky'ego i Braithwaite'a ${ }^{38}$.

34 T. Kundu, K. Szczygielski, Public Provision of Professional Services: Regulation and Welfare, Referat wygłoszony na konferencji Warsaw International Economic Meeting, 30.06.2016.

35 D.P. Baron, Credence attributes...

36 K. Szczygielski, Incentives and Power in Self-Regulatory Organizations, Referat wygłoszony na konferencji European Association for Research in Industrial Economics, 30.09.2017.

37 A.G. Heyes, A signaling motive for self-regulation in the shadow of coercion, Journal of Economics and Business 2005/57.3, s. 238-246.

38 P.N. Grabosky, J. Braithwaite, Of manners gentle: enforcement strategies of Australian business regulatory agencies, Oxford University Press, Oxford 1986, cyt. za: A. Ogus, Rethinking Self-Regulation... Również Grajzl i Baniak rozważają model podobny do tego z pracy Heyesa, ale zakładają nieco odmienną formę samoregulacji (P. Grajzl, A. Baniak, Industry self-regulation, subversion of public institutions, and social control of torts, International Review of Law and Economics 2009/29 (4), s. 360-374). 


\section{Podsumowanie i dyskusja}

W artykule został omówiony dorobek teorii ekonomii w badaniach nad profesjami. Przedyskutowane ujęcia teoretyczne pozwalają na wyciągnięcie kilku wniosków. Po pierwsze, istnieją silne argumenty za tym, że jeżeli profesja dostanie prawo do ustalania minimalnego standardu jakości, to ustali go na zbyt wysokim poziomie, aby stworzyć barierę wejścia. Ten wniosek nie jest specjalnie zaskakujący, zważywszy na założenia modeli. Trzeba jednak podkreślić, że nie oznacza to samo przez się, że brak minimalnego standardu jakości czy ustalenie takowego przez rząd są lepszymi rozwiązaniami. Warto też zauważyć, że w omówionych modelach usługi oferowane przez profesję faktycznie są wysokiej jakości (w dyskusjach politycznych troska profesji o jakość jest zwykle podawana w wątpliwość).

Po drugie, istnienie organizacji profesjonalnych ma uzasadnienie ekonomiczne $w$ tym sensie, że prawdopodobnie powstałyby one, nawet gdyby nie było to prawnie wymagane. Działoby się tak dlatego, że dla producentów korzystne może być stworzenie organizacji gwarantującej utrzymanie pewnego poziomu jakości. Co więcej, powstanie takich organizacji mogłoby być społecznie korzystne. $Z$ drugiej strony, istniejące rozwiązania instytucjonalne nie muszą być optymalne: w szczególności społecznie korzystne może być wprowadzenie „konkurencyjnej” samoregulacji.

Po trzecie, rząd powinien w pewnym zakresie sprawować nadzór nad rynkiem profesjonalnym. Szereg modeli teoretycznych sugeruje, że kiedy istnieje - być może nigdy nierealizowana - groźba regulacji czy kontroli ze strony rzą$\mathrm{du}$, organizacje profesjonalne wybierają rozwiązania społecznie korzystniejsze.

Omówione modele teoretyczne pokazują zarazem, jak bogatym tematem jest kwestia samoregulacji rynków profesjonalnych. Widać, że jest wciąż wiele tematów wartych rozszerzenia - na zasadzie rozwinięcia przedyskutowanych modeli - lub głębszego zbadania niektórych kwestii. Jedną z nich jest znaczenie wspomnianego we Wstępie etosu zawodowego. Można się zastanawiać, na przykład, kiedy etyka zawodowa stanowi wystarczający bodziec do tego, aby zachowywać się etycznie mimo pokus wynikających z asymetrii informacyjnej. Czy znaczenie ma wielkość profesji, czy historia, czy przykład jakichś wiodących jednostek $^{39}$, czy jeszcze jakieś inne czynniki? Jedyną $\mathrm{z}$ omówionych

39 Wpływ wiodących postaci na ewolucję norm społecznych jest przedmiotem modelu Acemoglu i Jacksona - D. Acemoglu, M.O. Jackson, History, Expectations, and Leadership in the Evolution of Social Norms, Review of Economic Studies 2015/82 (2), s. 423-456. 
powyżej prac, które podjęły ten temat, jest artykuł Barona ${ }^{40}$. Być może należy tu szerzej wykorzystać dorobek ekonomii behawioralnej.

Innym potencjalnie ciekawym kierunkiem badań byłoby otwarcie „,zarnej skrzynki”, jaką jest asymetria informacyjna. Jaki rodzaj informacji naprawdę daje profesjonalistom przewagę nad klientem? Jak wygląda gra między obydwiema stronami transakcji (chodzi tutaj o grę typu Milgroma i Robertsa ${ }^{41}$ ) i czy da się tak zmodyfikować jej reguły, aby zwiększyć dobrobyt społeczny? Jaką rolę odgrywa tu awersja do ryzyka po stronie konsumentów? Kolejnym problemem jest związek między stopniem i zakresem autonomii profesjonalnej a tempem wdrażania innowacji: jak się zdaje, poza artykułem Stefanadisa ${ }^{42}$ dorobek ekonomii jest tu niewielki.

Dalszych inspiracji dostarczyć może także literatura socjologiczna. Można tutaj znaleźć wątki, które, podobnie jak kwestia etyki zawodowej, są pozornie „nieekonomiczne”, podczas gdy faktycznie mają znaczenie dla rozwiązań instytucjonalnych i wyników rynkowych. Takim tematem jest walka profesjonalistów o prestiż społeczny jako motywacja do instytucjonalizowania zawodu. Innym, ale pokrewnym problemem, jest kwestia satysfakcji z wykonywania pracy profesjonalnej ${ }^{43}$. Zważywszy, że badania socjologiczne często polegają na - mało popularnych wśród ekonomistów - żmudnych studiach przypadków, sugerowane przez tę literaturę wątki mogą mieć duże znaczenie praktyczne.

\section{Bibliografia}

Abbott Andrew, The System of Professions: An Essay on the Division of Expert Labor, University of Chicago Press, Chicago 2014.

Acemoglu Daron, Jackson Matthew O., History, Expectations, and Leadership in the Evolution of Social Norms, Review of Economic Studies 2015/82 (2), s. 423-456.

Akerlof George A., The market for "lemons": Quality uncertainty and the market mechanism, Quarterly Journal of Economics 1970/84/3, s. 488-500.

Baron David P., Credence attributes, voluntary organizations, and social pressure, Journal of Public Economics 2011/95 (11-12), s. 1331-1338.

Baron David P., Morally Motivated Self-Regulation, American Economic Review 2010/100 (4), s. $1299-1329$.

40 D.P. Baron, Morally...

${ }^{41}$ P. Milgrom, J. Roberts, Relying on the information of interested parties, The RAND Journal of Economics 1986/17 (1), s. 18-32.

42 C. Stefanadis, op. cit.

43 M.S. Larson, op. cit., s. 59. 
Becker Gary S., A theory of competition among pressure groups for political influence, Quarterly Journal of Economics 1983/98 (3), s. 371-400.

Carr-Saunders Alexander M., Wilson Paul A., The professions, Oxford University Press, Oxford 1933.

Chaserant Camille, Harnay Sophie, Self-regulation of the legal profession and quality in the market for legal services: an economic analysis of lawyers'reputation, European Journal of Law and Economics 2015/39 (2), s. 431-449.

DeMarzo Peter M., Fishman Michael J., Hagerty Kathleen M., Self-Regulation and Government Oversight, Review of Economic Studies 2005/72 (3), s. 687-706.

Dulleck Uwe, Kerschbamer Rudolf, On Doctors, Mechanics, and Computer Specialists: The Economics of Credence Goods, Journal of Economic Literature 2006/XLVI, s. 5-42.

Freidson Eliot, The hospital in modern society, Free Press of Glencoe, New York 1963.

Freidson Eliot, Profession of Medicine, Dodd \& Mead, New York 1970.

Freidson Eliot, Professionalism, the third logic: on the practice of knowledge, University of Chicago Press, Chicago 2001.

Gehrig Thomas, Jost Peter-J., Quacks, lemons, and self-regulation: A welfare analysis, Journal of Regulatory Economics 1995/7.3, s. 309-325.

Grabosky Peter N., Braithwaite John J., Of manners gentle: enforcement strategies of Australian business regulatory agencies, Oxford University Press, Oxford 1986.

Grajzl Peter, Baniak Andrzej, Industry self-regulation, subversion of public institutions, and social control of torts, International Review of Law and Economics 2009/29 (4), s. 360-374.

Heyes Anthony G., A signaling motive for self-regulation in the shadow of coercion, Journal of Economics and Business 2005/57.3, s. 238-246.

Koten Silvester Van, Ortmann Andreas, Self-regulatory organizations under the shadow of governmental oversight: an experimental investigation, w: Sebastian J. Goerg, John R. Hamman, Experiments in Organizational Economics, Emerald Group Publishing Limited, Bingley 2016, s. 85-104.

Krause Eliot A., Death of the Guilds: Professions, States, and the Advance of Capitalism, 1930 to the Present, Yale University Press, New Haven 2016.

Kundu Tapas, Szczygielski Krzysztof, Public Provision of Professional Services: Regulation and Welfare, Referat wygłoszony na konferencji Warsaw International Economic Meeting, 30.06.2016.

Larson Magali S., The Rise of Professionalism: Monopolies of Competence and Sheltered Markets, ed. II, Transaction Publishers, New Jersey 2013

Leland Hayne E., Quacks, Lemons, and Licensing: A Theory of Minimum Quality Standards, Journal of Political Economy 1979/87 (6), s. 1328-1346.

Lima José L., Núñez Javier, Does self-regulation work? Experimental evidence of the reputational incentives of Self-Regulatory Organizations, Applied Economics 2015/47 (41), s. 4423-4441.

Maxwell John W., Lyon Thomas P., Hackett Steven C., Self-regulation and social welfare: The political economy of corporate environmentalism, The Journal of Law and Economics 2000/43 (2), s. 583-618.

Milgrom Paul, Roberts John, Relying on the information of interested parties, The RAND Journal of Economics 1986/17 (1), s. 18-32. 
Milton Friedman, Kuznets Simon, Income from Independent Professional Practice, National Bureau of Economic Research, Cambridge, MA 1954.

Núñez Javier, A model of self-regulation, Economics Letters 2001/74 (1), s. 91-97.

Núñez Javier, Can self-regulation work?: a story of corruption, impunity and cover-up, Journal of Regulatory Economics 2007/31 (2), s. 209-233.

Ogus Anthony, Rethinking Self-Regulation, Oxford Journal of Legal Studies 1995/15 (1), s. $97-108$.

Ogus Anthony, Self-regulation, w: Boudewijn Bouckaert, Gerrit de Geest (eds.), Encyclopedia of Law and Economics, t. 5, Edward Elgar, Cheltenham 2000, s. 587-602.

Shaked Avner, Sutton John, Heterogeneous consumers and product differentiation in a market for professional services, European Economic Review 1981/15 (2), s. 159-177.

Shaked Avner, John Sutton, Imperfect information, perceived quality, and the formation of professional groups, Journal of Economic Theory 1982/27 (1), s. 170-181.

Shaked Avner, Sutton John, The Self-Regulating Profession, Review of Economic Studies 1981/48 (2), s. 217-234.

Stefanadis Christodoulos, Self-Regulation, Innovation, and the Financial Industry, Journal of Regulatory Economics 2003/23 (1), s. 5-25.

Szczygielski Krzysztof, Incentives and Power in Self-Regulatory Organizations, Referat wygłoszony na konferencji European Association for Research in Industrial Economics, 30.09.2017.

Tullock Gordon, Efficient rent seeking, w: James B. Buchanan, Robert D. Tollison, Gordon Tullock (eds.), Toward a theory of the rent-seeking society, Texas A\&M University Press, College Station 1980.

Willner Johan, Professional associations and their members: A study of the market for professional services when ability and size are independent, International Journal of Industrial Organization 1985/3 (2), s. 179-195.

Krzysztof SZCZYGIELSKI

THE PROFESSIONAL AUTONOMY PROBLEM IN ECONOMIC STUDIES

(Su m mary)

Professions are occupations of a specific kind. They are characterized, in particular, by the information asymmetry of the services they provide: customers cannot, as a rule, assess the quality of these services. Classic examples of professions include doctors and lawyers, but several other occupations have at least some characteristics of professional groups. The article discusses and assesses the theoretical literature on professions, while stressing the phenomenon of professional self-regulation, its possible causes and consequences. Three broad topics are discussed in the review: self-regulation and barriers to entry to professional markets, self-regulatory organizations (SRO) as quality controllers, and SRO vs. government interventions. The theoretical literature reviewed in the article suggest that while professional organizations are in some sense natural, they tend to create barriers to entry, and governments should participate in regulating the professional markets. Possible further directions of research on professions are suggested.

Keywords: professional groups; professional autonomy; self-regulation; information asymmetry 